\title{
Analysis of Hospital Characteristics Affecting the Choice of Management Strategy Types: A Cross-Sectional Survey of Private Hospitals in Japan
}

\author{
Yuji Mitadera1, Mayumi Watanabe², Nobuhiro Sato', Motoi Azumi', Kouhei Akazawa² \\ ${ }^{1}$ Department of Medical Informatics and Statistics, Niigata University Graduate School of Medical and Dental Sciences, Niigata, \\ Japan \\ ${ }^{2}$ Department of Medical Informatics, Niigata University Medical and Dental Hospital, Niigata, Japan \\ Email: mitadera@daijo.shukutoku.ac.jp
}

How to cite this paper: Mitadera, Y. Watanabe, M., Sato, N., Azumi, M. and Akazawa, K. (2017) Analysis of Hospital Characteristics Affecting the Choice of Management Strategy Types: A Cross-Sectional Survey of Private Hospitals in Japan. Health, 9, 1494-1508.

https://doi.org/10.4236/health.2017.911110

Received: September 7, 2017

Accepted: October 20, 2017

Published: October 23, 2017

Copyright (๑) 2017 by authors and Scientific Research Publishing Inc. This work is licensed under the Creative Commons Attribution-NonCommercial International License (CC BY-NC 4.0). http://creativecommons.org/licenses/by-nc/4.0/ cC) (i) (8) Open Access

\begin{abstract}
The hospital environment in Japan has changed drastically lately. Its unpredictability has increased the need for hospitals to select management strategies to clarify their course. However, research on Japanese hospitals' management strategies has only recently begun with too few studies in this area. Hence, this study clarifies the management strategies of Japanese private hospitals. It explores the hospital characteristics that affect strategy selection. A questionnaire was mailed to 5682 private medical institutions in 2013, and 459 responses with no missing data were used for analysis. Factor analysis yielded four factors: "bed conversion and downsizing (Factor 1)," "diversification of medical and nursing care (Factor 2)," "expansion in business scale (Factor 3)," and "expansion of income from non-insured medical care (Factor 4)". Logistic regression analysis revealed that Year Founded (before 1965), Hospital Location (municipalities with populations smaller than 100,000), Hospital Type (psychiatric hospitals and mixed-care hospital), and Hospital Income and Expenditure (deficit) had significant positive impacts on the choice of Factor 1. For Factor 2, Hospital Type (sanatorium ward and mixed-care hospitals) and Hospital Income and Expenditure (constant surplus) had positive impacts. For Factor 3, Hospital Type (general hospital) and Bed Counts (more than 200) had positive impacts. For Factor4, Hospital Type (general hospital) had positive impacts. In other words, older hospitals, hospitals in rural areas, psychiatric hospitals, mixed-care hospitals, and hospitals with deficits tended to choose bed conversion and downsizing. Sanatorium ward hospitals, mixed-care hospitals, and hospitals with a constant surplus tended to choose
\end{abstract}


diversification of medical and nursing care. General hospitals and large hospitals tended to choose expansion in scale, and general hospitals tended to choose expansion into non-insured medical care. The planning of mid- to long-term management strategies suitable for each hospital and their steady execution are required.

\section{Keywords}

Hospital Management Strategies, Healthcare Management Planning, Hospital Diversification

\section{Introduction}

Japanese hospitals are classified into public hospitals established by the public organizations authorized by the Japanese Ministry of Health, Labor and Welfare and private hospitals established by nongovernment medical corporations. The 5721 private hospitals established by medical corporations constitute $67.4 \%$ of all hospitals in Japan [1]. A review of the financial conditions of these hospitals indicates a serious situation with $37.6 \%$ of private hospitals operating at a deficit [2]. The deficits of public hospitals are covered by public financing; therefore, most Japanese public hospitals do not face significant danger of insolvency.

However, private hospitals have no such coverage or sources of funding; continuous losses imply a high probability of excessive debt and, ultimately, bankruptcy. One hundred and thirteen private hospitals went bankrupt in Japan between 2000 and 2014 [3]. Private hospitals, like their public counterparts, play an important role in Japan's healthcare system. Hence, their bankruptcy impacts a large patient community. For example, hospital bankruptcy forces patients to interrupt necessary treatments. Thus, administrators of all hospitals, particularly private hospitals, need to "check" their management styles to avoid financial failure.

There is some accumulation of literature on hospital management, and much of it incorporates cost analysis. Blake and Healthcare Financial Management Association advocated drastic cost reductions by restructuring hospital processes and businesses [4] [5]. Additionally, Neriz [6] reported a meal cost reduction trial using activity-based costing, which calculated costs by allocating them to the associated service activities. In Japan, Shimomura and Kubo [7] analyzed the cost structure of hospital management and found differences in costs such as insurance assessment, salary expense, materials, medical materials, equipment, and depreciation expense between hospitals with a surplus and hospitals with a deficit. The authors provided practical and useful suggestions for hospital financial management and contributed to the stable management of hospitals.

On the other hand, the Japanese hospital environment has changed significantly. For example, aging has rapidly progressed, and the national medical-care system has undergone drastic reforms. With the current uncertainty, it is important for hospitals to select management strategies to clarify the direction in 
which they should proceed. There are some remarkable works concerning hospital management strategy.

Pioneering work was conducted by Ginn et al. [8] [9], who classified hospital management strategies into four types proposed by Miles et al. [10]. For example, Ginn and Young [8] surveyed the relationship between business strategy and the organizational and environmental characteristics of acute care hospitals. The authors found that small, independently operated hospitals were less likely to adopt a proactive strategy. Additionally, Ginn et al. [9] investigated the relationship between strategy and the financial structure of American hospitals and reported that hospitals with high liquidity and low leverage tended to select a defender strategy while hospitals with low liquidity and high leverage tended to select a prospector strategy. Moreover, Helmig et al. [11] surveyed the relation between German hospital characteristics and the typology. The authors stated that large-sized hospitals and teaching hospitals tended to select a prospector strategy while ownership and location were not related to strategy selection.

Other types of study include those that focus on the external hospital environment. Ahmad [12] investigated the relation between the external environment (government, economy, society, and technology) and the service strategies (establishing hospital brand, introducing new services, and offering various services) of Saudi Arabian hospitals. The results showed that the stability and transparency of government, increased buying power, rising health consciousness, and the introduction of new technology in diagnosis and treatment had positive effects on strategy adoption.

Many studies on hospitals' management strategies have been undertaken in various countries. In contrast, research on Japanese hospitals' management strategies has only recently begun, and a sufficient number of studies on this topic has not yet accumulated. This study, therefore, conducted a questionnaire survey among private hospitals operated by medical corporations to identify their management strategies. Moreover, the study examined the factors that influence hospitals' management strategy choices.

\section{Methods}

\subsection{Survey Subjects and Methods}

A self-administered questionnaire was mailed to 5682 medical institutions operated by medical corporations throughout Japan in March 2013. The questionnaire clarified the specific purpose of the study, the voluntary nature of the survey, the anonymization of hospital and personal data, and the limitations of these data regarding this study. Subjects were deemed to consent to the survey by returning the questionnaire. There were 535 (9.4\% response rate) respondents, and data analysis was performed on 459 hospitals with no missing data.

\subsection{Basic Hospital Characteristics}

The five basic characteristics of hospitals used in the analysis are year founded, 
hospital location, hospital type, bed count, and hospital income and expenditure (Table 1). Data on the year of hospital establishment were sorted into four categories: before 1965, 1965 to 1984,1985 to 1998 , and after 1998. Hospital locations were categorized into four population-based categories: large metropolitan areas with a population greater than 1 million, regional core cities of between 500,000 and 1 million, major regional cities of 100,000 to 500,000, and municipalities smaller than 100,000. Hospital types were categorized, according to prior research, into four categories: general hospitals, where general beds (beds mainly for acute patients) account for $80 \%$ or more of total beds; sanatorium-type hospitals, where long-term care beds account for $80 \%$ or more of total beds; psychiatric hospitals, where psychiatric beds account for $80 \%$ or more of total beds; and mixed-care hospitals that do not fit into the above categories. Four categories were used to classify bed capacity: less than 100, 100 to 199, 200 to 299, and 300 or more. Hospital income and expenditures were assigned a binary value for profitable entities considered to have a "constant surplus" during the three-year period from 2009 to 2011, with all others considered to be operating at a loss.

\subsection{Hospital Management Strategy Factors}

Based on previous works [13] [14], 15 questions were developed to identify hospital management strategy orientation (Table 2). Each question had four possible

Table 1. Basic hospital characteristic frequency distributions gathered by this survey $(n=459)$.

\begin{tabular}{|c|c|c|c|}
\hline & & $\mathrm{n}$ & $\%$ \\
\hline \multirow[t]{4}{*}{ Year Founded } & Before 1965 & 144 & 31.4 \\
\hline & $1965-1984$ & 171 & 37.3 \\
\hline & $1985-1998$ & 89 & 19.4 \\
\hline & After 1998 & 55 & 12.0 \\
\hline \multirow[t]{3}{*}{ Hospital Location } & Municipalities with populations smaller than 100,000 & 165 & 35.9 \\
\hline & Regional major cities with populations $100,000-500,000$ & 149 & 32.5 \\
\hline & Metropolitan areas with populations 500,000 or more & 145 & 31.6 \\
\hline \multirow[t]{4}{*}{ Hospital Type } & General hospital & 142 & 30.9 \\
\hline & Sanatorium ward hospital & 92 & 20.0 \\
\hline & Psychiatric hospital & 79 & 17.2 \\
\hline & Mixed-care hospital & 146 & 31.8 \\
\hline \multirow[t]{4}{*}{ Bed Count } & Less than 100 & 185 & 40.3 \\
\hline & $100-199$ & 167 & 36.4 \\
\hline & $200-299$ & 63 & 13.7 \\
\hline & $300+$ & 44 & 9.6 \\
\hline \multirow{2}{*}{ Hospital Income and Expenditure } & Constant surplus & 350 & 76.3 \\
\hline & Deficit & 109 & 23.7 \\
\hline
\end{tabular}


Table 2. Strategic orientation of hospitals (sorted by average, $\mathrm{n}=459$ ).

\begin{tabular}{|c|c|c|c|c|c|c|c|c|c|}
\hline & \multicolumn{2}{|c|}{$\begin{array}{l}\text { Definitely } \\
\text { Applies }\end{array}$} & \multicolumn{2}{|c|}{$\begin{array}{l}\text { Somewhat } \\
\text { Applies }\end{array}$} & \multicolumn{2}{|c|}{$\begin{array}{l}\text { Does Not } \\
\text { Really Apply }\end{array}$} & \multicolumn{2}{|c|}{$\begin{array}{l}\text { Absolutely Does } \\
\text { Not Apply }\end{array}$} & \multirow[t]{2}{*}{ Mean \pm S.D. } \\
\hline & $\mathrm{n}$ & $\%$ & $\mathrm{n}$ & $\%$ & $\mathrm{n}$ & $\%$ & $\mathrm{n}$ & $\%$ & \\
\hline $\begin{array}{l}\text { (1) Closer partnerships with other medical institutions, } \\
\text { nursing care facilities }\end{array}$ & 122 & 26.6 & 222 & 48.4 & 75 & 16.3 & 40 & 8.7 & $2.93 \pm 0.88$ \\
\hline (2) Better support function for in-home care & 89 & 19.4 & 182 & 39.7 & 100 & 21.8 & 88 & 19.2 & $2.59 \pm 1.01$ \\
\hline $\begin{array}{l}\text { (3) Promotion of combined management of medical and } \\
\text { nursing care }\end{array}$ & 68 & 14.8 & 194 & 42.3 & 90 & 19.6 & 107 & 23.3 & $2.49 \pm 1.01$ \\
\hline (4) Specialization in a certain area of medical care & 110 & 24.0 & 98 & 21.4 & 151 & 32.9 & 100 & 21.8 & $2.47 \pm 1.08$ \\
\hline $\begin{array}{l}\text { (5) Better preventive medical care through medical checkups, } \\
\text { screenings, and brain checkups }\end{array}$ & 52 & 11.3 & 135 & 29.4 & 120 & 26.1 & 152 & 33.1 & $2.19 \pm 1.02$ \\
\hline (6) Enhanced emergency care & 51 & 11.1 & 102 & 22.2 & 133 & 29.0 & 173 & 37.7 & $2.07 \pm 1.02$ \\
\hline $\begin{array}{l}\text { (7) Additional clinical departments and improvement of } \\
\text { comprehensive clinical functions through extension or } \\
\text { reconstruction of building }\end{array}$ & 26 & 5.7 & 99 & 21.6 & 151 & 32.9 & 183 & 39.9 & $1.93 \pm 0.92$ \\
\hline $\begin{array}{l}\text { (8) Expansion of revenues through specific medical expenses } \\
\text { and non-insured services such as private practices }\end{array}$ & 13 & 2.8 & 76 & 16.6 & 191 & 41.6 & 179 & 39.0 & $1.83 \pm 0.80$ \\
\hline (9) Expansion through new construction & 16 & 3.5 & 51 & 11.1 & 133 & 29.0 & 259 & 56.4 & $1.62 \pm 0.82$ \\
\hline (10) Getting rid of unprofitable clinical departments & 5 & 1.1 & 48 & 10.5 & 158 & 34.4 & 248 & 54.0 & $1.59 \pm 0.72$ \\
\hline (11) Reduction in surplus beds & 4 & 0.9 & 37 & 8.1 & 140 & 30.5 & 278 & 60.6 & $1.49 \pm 0.68$ \\
\hline $\begin{array}{l}\text { (12) Shifting businesses to fee-based homes for the elderly, } \\
\text { service-added housing for the elderly }\end{array}$ & 6 & 1.3 & 38 & 8.3 & 115 & 25.1 & 300 & 65.4 & $1.46 \pm 0.70$ \\
\hline (13) Expansion through acquisition & 6 & 1.3 & 35 & 7.6 & 113 & 24.6 & 305 & 66.4 & $1.44 \pm 0.69$ \\
\hline (14) Conversion of beds to elder care facilities & 1 & 0.2 & 36 & 7.8 & 117 & 25.5 & 305 & 66.4 & $1.42 \pm 0.64$ \\
\hline (15) Sale of businesses or closing of hospitals & 0 & 0.0 & 12 & 2.6 & 56 & 12.2 & 391 & 85.2 & $1.17 \pm 0.44$ \\
\hline
\end{tabular}

Averages and standard deviations were calculated using the following values: definitely -4 points, somewhat -3 points, not really -2 points, and absolutely not-1 point.

responses: "definitely applies,"“somewhat applies," "does not really apply," and "absolutely does not apply." Each response was given a point value between 4 and 1.

\subsection{Statistical Analysis}

The characteristics of the basic attributes of hospitals and questionnaire items are shown using mean and standard deviation (mean $\pm \mathrm{SD}$ ) for continuous variables and proportion for discrete variables.

Factor analysis with principal factor analysis and a varimax rotation was used to extract factors determining internal structures in the questionnaire items relating to hospital management strategy. After factors had been extracted, the scores of factor items were summed by individual subject, and the total scores of all subjects were divided into two groups of high and low median scores. 
Through this process, the factors were converted into dichotomous variables, which were also referred to as "hospital management strategy factors."Finally, a multiple logistic regression analysis with the management strategy as the dependent variable and the basic characteristics of hospitals as independent variables was performed to identify the significant variables affecting hospital management determination. The Hosmer-Lemeshow test evaluated the goodness-of-fit of the model. The statistical analysis was performed using IBM ${ }^{\circ}$ SPSS 19.0 software. The level of statistical significance was set to 0.05 .

\section{Results}

\subsection{Distribution of the Basic Characteristics}

Table 1 shows the distributions of factors used in the survey. For year founded, the highest number of hospitals was recorded between the years 1965 to 1984 at $37.3 \%$ followed by the period before the year 1965 at 31.4\%. For hospital location, $35.9 \%$ of hospitals were in municipalities with populations smaller than 100,000 followed by hospitals in regional major city locations with populations between 100,000 and 500,000 at 32.5\%. Next, was hospitals in metropolitan area locations with populations greater than 500,000 at $31.6 \%$.

Regarding hospital types, mixed-care and general hospitals accounted for $31.8 \%$ and $30.9 \%$ of the sample, respectively. The descriptive statistics showed that hospitals with fewer than 100 beds outnumbered all other hospital types and accounted for $40.3 \%$ of all hospitals. The proportion of hospitals that operated at a "constant surplus" (three consecutive years of profit) was $76.3 \%$.

\subsection{Overall Trends in Hospital Management Strategy}

Table 2 shows that among the 15 questionnaire items, "(1) closer partnerships with other medical institutions, nursing care facilities" had the highest mean value at $2.93 \pm 0.88$ (mean $\pm \mathrm{SD}$ ) followed by "(2) better support function for in-home care" at $2.59 \pm 1.01$, "(3) promotion of the combined management of medical and nursing care" at $2.49 \pm 1.01$, and "(4) specialization in a certain area of medical care" at $2.47 \pm 1.08$.

\subsection{Characteristics Affecting Management Strategy Decisions}

Categorization of management strategies: Factor analysis with 15 questionnaire items was performed to explore potential factors related to hospital management strategies (see Table 3). Among the results, five items (items 1, 4, 6, 7, and 10 in Table 2) had less than 0.4 factor load and were excluded from the interpretation of this factor analysis. Finally, four factors were generated based on 10 items. Cronbach's a coefficients for four factors; that is, Factor $i(i=1,2,3,4)$ was estimated at $0.643,0.696,0.711$, and 0.623 , respectively.

Factor 1 included the four items: "(14) conversion of beds to elder care facilities," "(12) shifting businesses to fee-based homes for the elderly, service-added housing for the elderly," "(11) reduction in surplus beds," and "(15) sales of 
Table 3. Result of factor analysis of management strategy $(n=459)$.

\begin{tabular}{|c|c|c|c|c|c|}
\hline & Factor 1 & Factor 2 & Factor 3 & Factor 4 & \\
\hline & $\begin{array}{l}\text { Bedconversion } \\
\text { and } \\
\text { downsizing }\end{array}$ & $\begin{array}{l}\text { Diversification } \\
\text { of medical and } \\
\text { nursing care }\end{array}$ & $\begin{array}{l}\text { Expansion } \\
\text { in business } \\
\text { scale }\end{array}$ & $\begin{array}{l}\text { Expansion of income } \\
\text { from non-insured } \\
\text { medical care }\end{array}$ & Commonality \\
\hline (14) Conversion of beds to elder care facilities & 0.701 & 0.225 & 0.028 & -0.012 & 0.543 \\
\hline $\begin{array}{l}\text { (12) Shifting businesses to fee-based homes for } \\
\text { the elderly, service-added housing for the elderly }\end{array}$ & 0.604 & 0.295 & 0.033 & 0.000 & 0.452 \\
\hline (11) Reduction in surplus beds & 0.464 & -0.020 & 0.116 & 0.019 & 0.229 \\
\hline (15) Sale of businesses or closing of hospitals & 0.461 & -0.079 & 0.072 & 0.055 & 0.227 \\
\hline $\begin{array}{l}\text { (3) Promotion of combined management of } \\
\text { medical and nursing care }\end{array}$ & 0.131 & 0.845 & 0.151 & 0.154 & 0.778 \\
\hline (2) Better support function for in-home care & 0.048 & 0.572 & 0.055 & 0.175 & 0.363 \\
\hline (13) Expansion through acquisition & 0.168 & 0.069 & 0.793 & 0.131 & 0.678 \\
\hline (9) Expansion through new construction & 0.078 & 0.116 & 0.652 & 0.152 & 0.468 \\
\hline $\begin{array}{l}\text { (8) Expansion of revenues through specific } \\
\text { medical expenses and non-insured services } \\
\text { such as private practices }\end{array}$ & 0.092 & 0.092 & 0.195 & 0.717 & 0.569 \\
\hline $\begin{array}{l}\text { (5) Better preventive medical care through } \\
\text { medical checkups, screenings, and brain } \\
\text { checkups }\end{array}$ & -0.029 & 0.224 & 0.089 & 0.597 & 0.415 \\
\hline Cronbach's $\alpha$ & 0.643 & 0.696 & 0.711 & 0.623 & \\
\hline Factor contribution & 1.347 & 1.263 & 1.146 & 0.968 & \\
\hline Aggregate contribution rate (\%) & 13.465 & 26.094 & 37.550 & 47.233 & \\
\hline
\end{tabular}

Factor loads were obtained by the principal factor method with varimax rotation. Bold values represent the highest loadings.

businesses or closing of hospitals," which were interpreted as "bed conversion and downsizing." Factor 2 consisted of two items: "(3) promotion of the combined management of medical and nursing care" and "(2) better support function for in-home care." These were interpreted as "diversification of medical and nursing care." Factor 3 was generated by "(9) expansion through new construction" and "(13) expansion through acquisition," and was labeled "expansion in business scale." Factor 4 included items "(8) expansion of revenues through specific medical expenses and non-insured services such as private practices" and "(5) better preventive medical care through medical checkups, screenings, and brain checkups," which was interpreted as "expansion of income from noninsured medical care."

We defined these factors as management strategy factors, which we relater used as dependent variables in the regression analyses.

Results of a multiple logistic regression analysis: Multiple logistic regression analysis was conducted with basic characteristics as independent variables and each management strategy factor as a dependent variable. Table 4 shows the results of multivariate analysis. 
Table 4. Result of multiple logistic regression analysis with management strategy factors as dependent variables $(n=459)$.

\begin{tabular}{|c|c|c|c|c|c|c|c|c|c|c|c|c|c|}
\hline \multirow[b]{3}{*}{ Variables } & \multirow[b]{3}{*}{ Category } & \multicolumn{3}{|c|}{ Factor 1} & \multicolumn{3}{|c|}{ Factor 2} & \multicolumn{3}{|c|}{ Factor 3} & \multicolumn{3}{|c|}{ Factor 4} \\
\hline & & \multicolumn{3}{|c|}{$\begin{array}{l}\text { Bed conversion } \\
\text { and downsizing }\end{array}$} & \multicolumn{3}{|c|}{$\begin{array}{l}\text { Diversification } \\
\text { of medical and } \\
\text { nursing care }\end{array}$} & \multicolumn{3}{|c|}{$\begin{array}{l}\text { Expansion in } \\
\text { business scale }\end{array}$} & \multicolumn{3}{|c|}{$\begin{array}{l}\text { Expansion of income } \\
\text { from non-insured } \\
\text { medical care }\end{array}$} \\
\hline & & $\begin{array}{l}\text { Odds } \\
\text { Ratio }\end{array}$ & $95 \% \mathrm{CI}$ & $\mathrm{p}$-value & Odds Ratio & $95 \% \mathrm{CI}$ & $\mathrm{p}$-value & $\begin{array}{l}\text { Odds } \\
\text { Ratio }\end{array}$ & $95 \% \mathrm{CI}$ & $\mathrm{p}$-value & $\begin{array}{l}\text { Odds } \\
\text { Ratio }\end{array}$ & $95 \% \mathrm{CI}$ & $\mathrm{p}$-value \\
\hline \multirow[t]{5}{*}{$\begin{array}{c}\text { Year } \\
\text { Founded }\end{array}$} & & & & 0.041 & & & 0.055 & & & 0.066 & & & 0.243 \\
\hline & Before $1965^{*}$ & 1 & & & 1 & & & 1 & & & 1 & & \\
\hline & $1965-1984$ & 0.755 & $\begin{array}{l}0.472- \\
1.206\end{array}$ & 0.239 & 1.885 & $\begin{array}{c}1.168- \\
3.041\end{array}$ & 0.009 & 0.912 & $\begin{array}{c}0.569- \\
1.459\end{array}$ & 0.700 & 1.473 & $\begin{array}{c}0.905- \\
2.396\end{array}$ & 0.119 \\
\hline & $1985-1998$ & 0.508 & $\begin{array}{c}0.286- \\
0.902\end{array}$ & 0.021 & 1.263 & $\begin{array}{c}0.708- \\
2.254\end{array}$ & 0.429 & 1.346 & $\begin{array}{c}0.758- \\
2.391\end{array}$ & 0.311 & 1.071 & $\begin{array}{c}0.597- \\
1.922\end{array}$ & 0.819 \\
\hline & After 1998 & 0.452 & $\begin{array}{c}0.232- \\
0.878\end{array}$ & 0.019 & 1.074 & $\begin{array}{c}0.549- \\
2.098\end{array}$ & 0.836 & 2.095 & $\begin{array}{c}1.066- \\
4.119\end{array}$ & 0.032 & 0.816 & $\begin{array}{c}0.415- \\
1.604\end{array}$ & 0.555 \\
\hline \multirow[t]{4}{*}{$\begin{array}{l}\text { Hospital } \\
\text { Location }\end{array}$} & & & & 0.038 & & & 0.061 & & & 0.089 & & & 0.697 \\
\hline & $\begin{array}{c}\text { Municipalities } \\
\text { with populations } \\
\text { smaller than } 100,000^{*}\end{array}$ & 1 & & & 1 & & & 1 & & & 1 & & \\
\hline & $\begin{array}{c}\text { Regional major } \\
\text { cities with populations } \\
100,000 \text { to } 500,000\end{array}$ & 0.582 & $\begin{array}{c}0.362- \\
0.934\end{array}$ & 0.025 & 0.612 & $\begin{array}{c}0.380- \\
0.984\end{array}$ & 0.043 & 1.101 & $\begin{array}{c}0.686- \\
1.765\end{array}$ & 0.691 & 0.865 & $\begin{array}{c}0.531- \\
1.408\end{array}$ & 0.559 \\
\hline & $\begin{array}{c}\text { Metropolitan areas } \\
\text { with populations } \\
500,000 \text { or more }\end{array}$ & 0.581 & $\begin{array}{c}0.353- \\
0.956\end{array}$ & 0.032 & 0.596 & $\begin{array}{c}0.361- \\
0.983\end{array}$ & 0.043 & 1.702 & $\begin{array}{c}1.033- \\
2.804\end{array}$ & 0.037 & 0.806 & $\begin{array}{c}0.481- \\
1.351\end{array}$ & 0.413 \\
\hline \multirow[t]{5}{*}{$\begin{array}{c}\text { Hospital } \\
\text { Type }\end{array}$} & & & & 0.018 & & & 0.001 & & & 0.001 & & & 0.001 \\
\hline & General hospital ${ }^{*}$ & 1 & & & 1 & & & 1 & & & 1 & & \\
\hline & $\begin{array}{l}\text { Sanatorium } \\
\text { ward hospital }\end{array}$ & 1.586 & $\begin{array}{c}0.888- \\
2.834\end{array}$ & 0.119 & 2.497 & $\begin{array}{c}1.387- \\
4.497\end{array}$ & 0.002 & 0.459 & $\begin{array}{c}0.253- \\
0.832\end{array}$ & 0.010 & 0.241 & $\begin{array}{c}0.132- \\
0.438\end{array}$ & 0.001 \\
\hline & Psychiatric hospital & 2.884 & $\begin{array}{c}1.466- \\
5.677\end{array}$ & 0.002 & 1.068 & $\begin{array}{c}0.541- \\
2.109\end{array}$ & 0.849 & 0.400 & $\begin{array}{c}0.203- \\
0.787\end{array}$ & 0.008 & 0.099 & $\begin{array}{c}0.046- \\
0.212\end{array}$ & 0.001 \\
\hline & $\begin{array}{l}\text { Mixed-care } \\
\text { hospital }\end{array}$ & 1.794 & $\begin{array}{l}1.059- \\
3.037\end{array}$ & 0.030 & 2.476 & $\begin{array}{c}1.448- \\
4.234\end{array}$ & 0.001 & 1.241 & $\begin{array}{c}0.731- \\
2.105\end{array}$ & 0.423 & 0.671 & $\begin{array}{c}0.392- \\
1.149\end{array}$ & 0.001 \\
\hline \multirow[t]{5}{*}{$\begin{array}{c}\text { Bed } \\
\text { Count }\end{array}$} & & & & 0.638 & & & 0.204 & & & 0.011 & & & 0.849 \\
\hline & Less than $100^{*}$ & 1 & & & 1 & & & 1 & & & 1 & & \\
\hline & $100-199$ & 1.085 & $\begin{array}{c}0.682- \\
1.727\end{array}$ & 0.731 & 0.965 & $\begin{array}{c}0.601- \\
1.549\end{array}$ & 0.882 & 1.518 & $\begin{array}{c}0.949- \\
2.428\end{array}$ & 0.082 & 1.150 & $\begin{array}{c}0.712- \\
1.856\end{array}$ & 0.568 \\
\hline & $200-299$ & 1.259 & $\begin{array}{c}0.655- \\
2.418\end{array}$ & 0.490 & 1.460 & $\begin{array}{c}0.745- \\
2.861\end{array}$ & 0.270 & 2.917 & $\begin{array}{c}1.478- \\
5.760\end{array}$ & 0.002 & 0.998 & $\begin{array}{c}0.505- \\
1.972\end{array}$ & 0.994 \\
\hline & $300+$ & 1.640 & $\begin{array}{c}0.755- \\
3.562\end{array}$ & 0.211 & 2.063 & $\begin{array}{c}0.938- \\
4.539\end{array}$ & 0.072 & 2.493 & $\begin{array}{c}1.152- \\
5.395\end{array}$ & 0.020 & 1.357 & $\begin{array}{c}0.603- \\
3.054\end{array}$ & 0.460 \\
\hline Hospital & Deficit $^{*}$ & 1 & & & 1 & & & 1 & & & 1 & & \\
\hline $\begin{array}{l}\text { income and } \\
\text { expenditure }\end{array}$ & Constant surplus & 0.624 & $\begin{array}{c}0.393- \\
0.990\end{array}$ & 0.045 & 2.013 & $\begin{array}{c}1.258- \\
3.223\end{array}$ & 0.004 & 0.895 & $\begin{array}{c}0.565- \\
1.418\end{array}$ & 0.637 & 0.980 & $\begin{array}{c}0.610- \\
1.576\end{array}$ & 0.935 \\
\hline \multicolumn{2}{|c|}{ Hosmer-Lemeshow Test } & \multicolumn{3}{|c|}{$P=0.150$} & \multicolumn{2}{|c|}{$P=0.876$} & & \multicolumn{3}{|c|}{$=0.705$} & \multicolumn{3}{|c|}{$P=0.397$} \\
\hline
\end{tabular}

${ }^{*}$ Reference Category. 
For Factor 1, "bed conversion and downsizing," several characteristics were found to have statistically significant impacts including Year Founded ( $\mathrm{p}=$ $0.041)$, Hospital Location ( $p=0.038)$, Hospital Type $(\mathrm{p}=0.018)$, and Hospital Income and Expenditure $(\mathrm{p}=0.045)$. For Factor 2, "diversification of medical and nursing care," Hospital Type $(\mathrm{p}=0.001)$ and Hospital Income and Expenditure ( $\mathrm{p}=0.004)$ were selected as significant influencing characteristics. The logistic regression analysis of Factor 3, "expansion in business scale," showed that Hospital Type $(\mathrm{p}=0.001)$ and Bed Count $(\mathrm{p}=0.011)$ were significant. Additionally, in the analysis of Factor 4, "expansion of income from non-insured medical care," Hospital Type ( $\mathrm{p}=0.001)$ was selected as a significant influencing characteristic.

\section{Discussion}

Factor analysis was performed on the 15 questionnaire items concerning hospital management strategies and, consequently, four management strategy factors were obtained. Then, a multiple logistic regression analysis was conducted using these management strategy factors as dependent variables and the basic characteristics of hospitals as independent variables. Based on the results, we discuss the relationship between hospital management strategies and basic hospital attributes.

Factor 1, "bed conversion and downsizing": Year Founded, Hospital Location, Hospital Type, and Hospital Income and Expenditure affected this factor. For Year Founded, older hospitals tended to choose conservative strategies, such as downsizing, selling or closing businesses, and the conversion of beds to elderly care facilities. This could be explained by the institution life cycle hypothesis, which states that hospitals transition between stages of boom and bust, diversification, divestiture, and conclude with closure or merger over time [15]; that is, older hospitals are at a declining stage of the life cycle and prefer conservative strategies such as downsizing or bed conversion. Another possible explanation is manager age. Managers of older hospitals tend to be older than managers of newer hospitals, and typically, older people tend to adopt conservative strategies. Serfling (2014) reported that older CEOs prefer less risky investment policies than younger CEOs [16].

For Hospital Location, hospitals located in municipalities with populations smaller than 100,000 were likely to select bed conversion and downsizing. The mean population growth rates by municipality size from 2005 to 2010 in Japan show that municipalities with populations smaller than 100,000 tended to be negative while those of municipalities with a population greater than 300,000 tended to be positive [17].

Moreover, according to Ehara [18], there are minimum municipality population sizes required for hospitals to operate their departments. For example, a population size of at least 100,000 is required for nephrology, psychosomatic medicine, thoracic surgery, cardiovascular surgery, plastic surgery, and gyne- 
cology departments; 200,000 is required for hematology, rheumatology, breast surgery, and colorectal surgery departments; 300,000 is required for cosmetic surgery, pediatric surgery, and obstetrics departments; and 500,000 is required for allergology departments. This implies that it is difficult for hospitals located in municipalities with populations smaller than 100,000 to run their businesses with the same size population as before because they are required to consider new management strategies including downsizing or bed conversion.

For Hospital Type, psychiatric hospitals were 2.884 times more likely to choose "bed conversion and downsizing" than general hospitals; that is, many psychiatric hospitals were planning to improve their business by reducing spare bed capacity or transferring their spare beds to nursing care use.

The strategy of these hospitals was affected by the overabundance of psychiatric beds. As of 2014, there were 2.66 beds in psychiatric hospitals for every 1,000 people in Japan, ranking Japan first among the 28 OECD member nations [19]. Moreover, in 2004, the Japanese government presented "A Vision for Reforming Mental Health Care," which has promoted a policy shift away from inpatient medical care toward local community care [20]. The anticipated impact of this policy is a further reduction in the number of hospital beds in psychiatric hospitals and a shift to medical care provision in local communities.

For Hospital Income and Expenditure, the odds ratio of hospitals having a constant surplus in their medical income and expenditures is 0.624 , which implies that many hospitals facing a deficit are considering "bed conversions and downsizing," and apparently, many hospitals are planning to improve their bottom lines through bed conversion or decreasing the number of beds. Previous work also reported that the lower the operating profit, the lower the level of aggressiveness in hospital business diversification [21].

Factor 2, "diversification of medical and nursing care": Hospital Type and Hospital Income and Expenditure influenced this factor. For Hospital Type, sanatorium and mixed-care hospitals were more likely to choose "diversification of medical and nursing care," which is based on a business model wherein companies implement nursing facilities and at-home services in addition to hospitals and provide a combination of medical and nursing services.

This finding could be explained as follows. Recently, the rapid progress of aging and advancing medical technology have increased the national medical expenditure and the number of elderly who are hospitalized long term. The proportion of the population aged 65 and over was $26 \%$ in 2014 and is forecasted to reach $39.9 \%$ in 2060 [22]. The national medical care expenditure reached 40.8071 trillion yen in FY 2014 (an increase of 746.1 billion yen or 1.9\% from the previous fiscal year) [23]. To suppress the expenditure, the Japanese government introduced incentives promoting early discharge and conversion from hospitalized care to at-home medical or at-facility nursing care [24]. This forced sanatorium and mixed-care hospital discharging of chronic elder patients affecting a considerable number of patients. However, there were insufficient facilities or 
at-home services in Japan to accept the patients, and the hospitals diversified into other businesses, such as at-home medical care, nursing care facilities, or at-home service offices, to realize early discharge.

This diversified management has already been reported in the past and in other countries. For example, Niki [25] reported that hospitals diversified into elderly nursing care and formed trifectas of hospitals, geriatric health service facilities, and special nursing homes for the elderly in Japan.

In the United States, facing economic pressures and demographic changes, acute care hospitals diversified their businesses into long-term care such as long-term care units or home health services [26]. Some hospitals opened assisted living facilities for long-term care to alleviate troubles after discharge, such as when transitioning to nursing facilities [27]. Additionally, some Korean hospitals transformed hospitalized medical care into at-home nursing care [28].

For Hospital Income and Expenditure, constant surplus hospitals were 2.013 times more likely to choose "diversification of medical and nursing care" than deficit hospitals. This could be attributed to the financial abundance of constant surplus hospitals, which increased their intentions to enter new markets such as nursing care services or at-home medical care. A previous study also noted that operating profits provided firms with the means to diversify [15].

Factor 3, "expansion in business scale": Hospital Type and Bed Count influenced this factor. For Hospital Type, sanatorium and psychiatric hospitals were less likely to choose expansion. This could be explained with the same reasoning as Factor 2; that is, the Japanese government's policy of reducing psychiatric and elderly beds affected hospital decisions.

For Bed Count, large hospitals with more than 200 beds were more likely to adopt a business expansion strategy; that is, large hospitals tried to pursue "economies of scale" by owning and chaining multiple hospitals. Bed counts are regulated in Japan, and corporations cannot newly open hospitals or increase beds in an area with more beds than the standard bed count (excessive bed count area). Therefore, large hospitals pursue economies of scale through M \& A to expand to other areas. The effect of economies of scale has been observed in other countries. For instance, using data on independent hospital mergers, Dranove and Lindrooth [29] found that post-merger cost decreased by $14 \%$ indicating that economies of scale hold to some degree.

Finally, although not significant, the p-value of Hospital Location was 0.089, and the odds ratio of metropolitan areas with populations of more than 500,000 was 1.702. This implies that hospitals located in large metropolitan areas were more likely to choose business expansion. This could be explained by the prediction that the numbers of patients would increase sharply in large metropolitan areas, such as Tokyo, Kanagawa, Nagoya, Osaka, and Hiroshima prefectures from 2011 to 2020 [30]. The research of Komatsu et al. [31] forecasting hospitalization demand also suggested that there will be an explosive increase in medical care demand in urban areas, particularly in the Tokyo metropolitan area, 
which includes Tokyo, Saitama, Kanagawa, and Chiba prefectures. Moreover, Komatsu [31] noted that, if the supply of these medical services is not increased, there will be many elderly people unable to receive necessary medical care.

Factor 4, "expansion of income from non-insured medical care": Hospital Type was the only characteristic affecting this factor. The aggressive expansion of non-insured services, such as health checkups, complete physical examinations, preventive care, and optional services, is more common among general hospitals (medical checkups and advanced services are not insured under the Japanese medical system). The reason could be that general hospitals have more physicians and advanced examination equipment than other hospitals and, thus, have an easier time providing non-insured services.

Cancer screening rates in Japan are lower than those of other OECD countries. For instance, the breast cancer screening rate of Japan was only $41 \%$ compared to $80.8 \%, 75.1 \%$, and $75 \%$ for the United States, the United Kingdom, and France, respectively. The cervical cancer screening rate of Japan was $42.1 \%$ compared to $84.5 \%, 76.9 \%$, and $75.4 \%$ for the aforementioned countries, respectively [32]. The Japanese government set a target of raising screening rates to $50 \%$ ( $40 \%$ for stomach, lung, and large bowel cancers for some time) within five years in the "Basic Plan to Promote Anti-Cancer Measures" [33]. General hospitals should aggressively diversify into the expanding markets of health checkups and complete physical examinations in the environment where an increase in insured medical care income cannot be expected because of a huge national financial deficit and a shrinking population.

The results of this study could contribute to hospital management in both practical and theoretical aspects. From a practical perspective, the study data are valuable for hospital administrators, managers, and policy makers in planning mid- to long-term strategies based on their hospital characteristics. From a theoretical perspective, the relationship between hospital characteristics and management strategy choice is clarified in Japan for the first time.

However, this study does have limitations. We considered location, founding year, hospital type, bed count, and hospital income and expenditure in hospital management strategy selection, but a number of external factors (medical demand in the hospital vicinity or competing hospitals) as well as internal factors (areas of specialty, facility equipment, or personnel) should also be considered.

\section{Conclusion}

In summary, this study clarifies that each Japanese private hospital chooses its strategy type according to its characteristics. Older hospitals, hospitals in rural areas, psychiatric hospitals, mixed-care hospitals, and hospitals with deficits tended to choose "bed conversion and downsizing." Sanatorium ward hospitals, mixed-care hospitals, and hospitals with a constant surplus tended to choose "diversification of medical and nursing care." General hospitals and large hospitals tended to choose "expansion in scale," and general hospitals tended to 
choose "expansion into non-insured medical care."

\section{Acknowledgements}

We give sincere thanks to hospital managers who participated in our survey.

\section{Funding}

This study was supported by JSPS KAKENHI (Grant-in-Aid for Scientific Research) Grant Number 23530802.

\section{Competing Interest}

The authors have no competing interests to report.

\section{References}

[1] Statistics and Information Department, Minister's Secretariat, Ministry of Health, Labour and Welfare (2014) Summary of Static/Dynamic Surveys of Medical Institutions and Hospital Report (In Japanese). http://www.mhlw.go.jp/toukei/saikin/hw/iryosd/14/dl/1-1.pdf

[2] Japan Hospital Federation, Japan Hospital Association (2013) Byouin Unei Jittai Bunseki Chousa no Gaiyou [An Overview of a Survey of the State of Hospital Management]. (In Japanese).

[3] Teikoku Databank (2015) Iryou Kikan/Roujin Fukushi Jigyousha no Tousan Doukou Chousa. [A Survey of Bankruptcy Trends in Medical Institutions and Elderly Care Providers.] (In Japanese) https://www.tdb.co.jp/report/watching/press/pdf/p150102.pdf

[4] Blake, J.W., Channon, B.S., Gruve, M.E. and Sussman, J.A. (2012) A Guide to Strategic Cost Transformation in Hospitals and Health Systems. Health Research \& Educational Trust and Kaufman, Hall \& Associates, Inc., Chicago.

http://www.hpoe.org/Reports-HPOE/guide_strategic_cost_transformation_hospital s_health_systems.pdf

[5] Healthcare Financial Management Association (2012) Educational Report-Hospital Strategies for Process-Based Cost Reduction. Healthcare Financial Management, 66, 1.

[6] Neriz, L., Núñez, A. and Ramis, F.A. (2014) Cost Management Model for Hospital Food and Nutrition in a Public Hospital. BMC Health Services Research, 14, 542. https://doi.org/10.1186/s12913-014-0542-0

[7] Shimomura, K. and Kubo, R. (2011) Quantitative Analysis of Cost Structures in Hospital Management: Comparison between Groups of Surplus and Deficit Hospitals Belonging to the National Hospital Organization. Journal of the Japan Society for Healthcare Administration, 48, 129-136.

[8] Ginn, G.O. and Young, G.J. (1992) Organizational and Environmental Determinants of Hospital Strategy. Hospital \& Health Services Administration, 37, 291.

[9] Ginn, G.O., Young, G.J. and Beekun, R.I. (1995) Business Strategy and Financial Structure: An Empirical Analysis of Acute Care Hospitals. Hospital \& Health Services Administration, 40, 191.

[10] Miles, R.E., Snow, C.C., Meyer, A.D. and Coleman, H.J. (1978) Organizational Strategy, Structure, and Process. The Academy of Management Review, 3, 546-562. https://www.jstor.org/stable/pdf/257544.pdf 
[11] Helmig, B., Hinz, V. and Ingerfurth, S. (2014) Extending Miles \& Snow's Strategy Choice Typology to the German Hospital Sector. Health Policy, 118, 363-376. https://doi.org/10.1016/j.healthpol.2014.06.006

[12] Ahmad, A.E.M.K. (2012) Macro-Environment Influences on Health Service Strategy in Saudi Private Sector Hospitals. International Business Research, 5, 49-64.

[13] Tomita, M., Yoshimura, K. and Ikegami, N. (2010) Impact of Home and Community-Based Services on Hospitalisation and Institutionalisation among Individuals Eligible for Long-Term Care Insurance in Japan. BMC Health Services Research, 10, 345. https://doi.org/10.1186/1472-6963-10-345

[14] Kumar, K., Subramanian, R. and Strandholm, K. (2011) Market Orientation and Performance: Does Organizational Strategy Matter? Journal of Applied Business Research, 18, 37-50. https://doi.org/10.19030/jabr.v18i1.2099

[15] Eastaugh, S.R. (2014) Hospital Diversification Strategy. Journal of Health Care Finance, 40, 1-13.

[16] Serfling, M.A. (2014) CEO Age and the Riskiness of Corporate Policies. Journal of Corporate Finance, 25, 251-273.

[17] Ministry of Land, Infrastructure, Transport and Tourism (2012) White Paper on Land, Infrastructure, Transport and Tourism in Japan. http://www.mlit.go.jp/hakusyo/mlit/h23/hakusho/h24/index.html

[18] Ehara, A. (2013) Medical Specialties and Population Size of Municipalities in Japan. Iryo To Shakai, 23, 113-123. https://www.jstage.jst.go.jp/article/iken/23/2/23_113/_pdf https://doi.org/10.4091/iken.23.113

[19] OECD Health Statistics (2016) Frequently Requested Data. http://stats.oecd.org/index.aspx?DataSetCode=HEALTH_STAT\#

[20] Matsuda, R. (2009) Review of Mental Health Care Reform. Kinugasa Research Institute, Ritsumeikan University, 14. http://hpm.org/en/Surveys/Ritsumeikan_University___Japan/14/Review_of_Mental _Health_Care_Reform.html

[21] Eastaugh, S.R. (2008) Diversification in the Hospital Industry. Journal of Health Care Finance, 34, 52-65.

[22] Cabinet Office Japan (2014) The Aging Society: Current Situation and Implementation Measures FY 2013. Annual Report on the Aging Society. http://www8.cao.go.jp/kourei/english/annualreport/2015/pdf/c1-1.pdf

[23] Ministry of Health, Labour and Welfare (2014) Estimates of National Medical Care Expenditure, FY 2014. http://www8.cao.go.jp/kourei/english/annualreport/2015/2015pdf_e.html

[24] Kinjo, K., Sairenji, T., Koga, H., Osugi, Y., Yoshida, S., Ichinose, et al. (2017) Cost of Physician-Led Home Visit Care (Zaitaku Care) Compared with Hospital Care at the End of Life in Japan. BMC Health Services Research, 17, 40. https://doi.org/10.1186/s12913-016-1961-x

[25] Niki, R. (1998) Combining Health, Medicine, and Welfare (Hoken Iryou Fukushi Fukugoutai). IgakuShoin, 97.

[26] Shah, A., Fennell, M. and Mor, V. (2001) Hospital Diversification into Long-Term Care. Health Care Management Review, 26, 86-100. https://doi.org/10.1097/00004010-200107000-00009

[27] Stone, R.I. and Reinhard, S.C. (2007) The Place of Assisted Living in Long-Term Care and Related Service Systems. The Gerontologist, 47, 23-32. 
https://doi.org/10.1093/geront/47.Supplement_1.23

[28] Noh, J.-W., Kwon, Y.-D., Yoon, S.-J. and Hwang, J.-I. (2011) Internal and External Environmental Factors Affecting the Performance of Hospital-Based Home Nursing Care. International Nursing Review, 58, 263-269. https://doi.org/10.1111/j.1466-7657.2010.00868.x

[29] Dranove, D. and Lindrooth, R. (2003) Hospital Consolidation and Costs: Another Look at the Evidence. Journal of Health Economics, 22, 983-997. https://doi.org/10.1016/j.jhealeco.2003.05.001

[30] Ehara, A. (2011) Forecast of Changes in the Number of Outpatients and Inpatients in Each Japanese Prefecture from 2005 to 2020. Japan Medical Association Journal, 54, 325-328.

[31] Komatsu, J., Watanabe, M. and Kameda, S. (2012) Calculating Basic Bed Counts in Medical Planning and a Forecast of Hospitalization Demand using Regional Populations. Kousei no Shihyou, 59, 7-13. (In Japanese)

[32] OECD, OECD Health Statistics (2016) Health Care Utilisation: Screening. http://stats.oecd.org/index.aspx? ?ataSetCode=HEALTH_STAT

[33] Ministry of Health, Labour and Welfare (2012) The Basic Plans to Promote Anti-Cancer Measures. (In Japanese)

http://www.mhlw.go.jp/bunya/kenkou/dl/gan_keikaku02.pdf 